\title{
Implementation of Value Added Tax Policy on Pharmaceutical in Indonesia
}

\author{
Titi Muswati Putranti ${ }^{1}$, Amri Rafli ${ }^{2}$ \\ \{titi.putranti@gmail.com ${ }^{1}$, amri.rafli@gmail.com²\} \\ Universitas Indonesia, +62 816-774-055', Universitas Indonesia, +62 $85921255753^{2}$
}

\begin{abstract}
This study aims to analyze the differences in treatment of value-added tax (VAT) on the delivery of pharmaceutical preparations from a pharmaceutical wholesaler (Pedagang Besar Farmasi/PBF) to private and government hospital pharmacy installation (Instalasi Farmasi Rumah Sakit/IFRS) with using post-positivist approach. Qualitative data collection will be analyzed with quantitative technical analysis. The VAT policy on the delivery of pharmaceutical preparations has two VAT collection techniques, a selfassessment system and withholding tax system. The results of this research show that a withholding tax system is a form of deviation from the normal mechanism. However, the government realized that the withholding tax system needed to be done given the low level of taxable entrepreneur (Pengusaha Kena Pajak/PKP) compliance. Administratively, the withholding tax system that applied to the delivery of pharmaceutical preparations also results in inefficiencies in both the PBF business and government revenue.
\end{abstract}

Keywords: Tax policy, value added tax, neutrality, efficiency, pharmaceutical.

\section{Introduction}

Good health and well-being for all ages are one of the goals of the Sustainable Development Goals (SDGs). Indonesia, along with more than 190 countries, is committed to achieving targets in the health sector by 2030 [1]. The success in achieving the SDGs goals and targets is inseparable from the critical role of the government. The health sector is a priority because it will have a direct impact on the quality of human resources and human welfare.

Every citizen has the same right in gaining access to health. The right to health is one of the elements of welfare that must be realized by the government. Government responsibilities in the health sector are stipulated in Article 14 Law No. 36 the year 2009 in planning, organizing, fostering, and supervising administration in the health sector [2].

One of the priorities of the Ministry of Health's Strategic Plan for 2015-2019 is ensuring the availability and quality of pharmaceutical preparations for the public [3] [4]. Pharmaceutical preparations in Indonesia, especially drugs and medicinal ingredients, are classified as highly regulated goods. Ranging from production facilities, distribution facilities, to pharmaceutical service facilities are regulated by the government [5]. Production facilities consist of the pharmaceutical industry, the pharmaceutical raw materials industry, the traditional medicine industry, and the cosmetics factory. Domestic drug production has reached almost $90 \%$ of national drug needs. But the pharmaceutical industry still relies on 
$96 \%$ of imported raw materials. Whereas the raw material component of the drug contributes $25 \%$ to $30 \%$ of the total cost of drug production, so intervention in this component will have an impact on drug prices.

Distribution facilities consist of pharmaceutical wholesalers and pharmaceutical preparations. Pharmacy service facilities include pharmacies, hospital pharmacy installations, health centers, clinics, drug stores, or joint practices. The three facilities provide pharmaceutical services by the business level set by the government [6] [7].

One of the pharmaceutical service facilities is the Hospital Pharmacy Installation (IFRS) which is a function implementing unit that organizes all pharmaceutical service activities or activities at the Hospital or the party that guarantees the supply and distribution of pharmaceutical preparations to patients at the Hospital [7]. The number of hospitals in Indonesia in 2017 was 2867 organized by government hospitals, state-owned enterprises, nonprofit and private organizations [8]. So that the drag chain can be described as follows: Drug Manufacturers $\rightarrow$ Pharmaceutical Wholesalers (PBF) $\rightarrow$ Installation Hospital Pharmacy (IFRS) $\rightarrow$ Buyer / Patient. IFRS is only allowed to purchase pharmaceutical preparations from distributors who obtain permits from the government [5], namely PBF [9].

Based on Article 4 paragraph (1) of Law No.42 / 2009 [10], the supply of pharmaceutical preparations by the PBF to the IFRS is subject to VAT at $10 \%$. IFRS, which is a function implementing unit of the Hospital can be done by the government and the private sector. There is a different treatment between the supply of pharmaceutical preparations from PBF to government and private IFRS. In Indonesia, there are two collection techniques, namely the self-assessment system and the withholding tax system [11]. In the self-assessment system, taxable person is required to implement a periodic self-assessment system (monthly basis) and pay the net amount of tax (difference in net output tax - input tax) to the state treasury. The taxable person also acts as an assessor and tax collector because most of the initiation of taxation activities (including reporting efforts to obtain a taxable person identity) comes from the taxable entrepreneur. In contrast to this, the withholding tax system emphasizes tax collection to the consumer.

When supply of pharmaceutical preparations is made by PBF to private IFRS, the VAT is collected by PBF. This is a consequence of the indirect tax that PBF acts as a VAT collector. While supply of pharmaceutical preparations is made by PBF to the government IFRS, the VAT is collected by IFRS treasurer as the buyer. This is regulated explicitly in Article 16A of Law No.18 / 2000 [12] where the government treasurer is appointed as a VAT collector. This collection mechanism is a reverse charge mechanism where buyers/consumers collect VAT on themselves [13]. The provisions in the VAT Law require buyers as VAT Collectors to collect, pay, and report VAT. This provision resulted in a shift in the obligation to collect VAT from PBF sellers as PKP to IFRS buyers through government treasurers.

The collection of VAT by Government IFRS will cause the Input Tax charged by PBF always to be higher. PBF will always overpaid VAT because PBF no longer takes into account the VAT owed as Output Tax. Whereas, since the inception of VAT in 1985 until now, Indonesia has adopted a simple fourth model in its implementation. This method is the most commonly used in calculating VAT in several countries [14]. Through this method, enterpreneurs at every level of production up to distribution charge VAT on their sales to consumers (the VAT on its output), credit the VAT that was paid at the time of purchase (the VAT on its input) and pay taxes to the State Treasury [15]. Although PBF's taxation rules have the right to make monthly VAT refund and preliminary returns [16], the refund process will add an administrative burden to PBF. Around Rp1.5 to 2 trillion VAT refund claimed by PBF every year [17]. VAT refunds can take about two years. It will cause the additional burden of 
working capital and PBF resources and adds to the cost of working capital interest which is equivalent to 3 to $4 \%$ of the PBF sales value [17]. An additional expenses on similar transactions will result in inefficiencies in the PBF business and reduce the net profit that can be generated by PBF. Whereas, the VAT policy must be enforced with due regard to the principles of neutrality [18] and efficiency for both business and government. The principle of neutrality which emphasizes that the tax imposed on taxpayers must be free from distortion, both for consumption and production as well as other economic factors [19]. Also, the policy of collecting VAT is intended to secure state revenue and prevent the practice of VAT fraud by PKP [20].

\section{Methodology}

This post-positivist study aims to analyze the differences in the treatment of VAT on the delivery of pharmaceutical preparations from PBF to private and government IFRS. Qualitative data collection includes primary data obtained through in-depth interviews and observations and secondary data obtained through the study of literature or literature will be analyzed with quantitative technical analysis [21]. Valid data and quality information resulted from interviews with the Directorate General of Tax, the Fiscal Policy Agency, Pharmaceutical Wholesalers, Government Hospitals, Private Hospitals, and Academics. Site research conducted in Jakarta.

\section{Result}

The main interest in the tax collection policy for the state is raising the revenue or the achievement of a sustainable source of state revenue [22]. The indicator used in analyzing the revenue productivity of VAT collection on the delivery of pharmaceutical preparations by PBF to Government and Private Hospitals is the effectiveness of revenue in which VAT receipts depend on the amount of VAT deposited to the state by those who are required to collect owed VAT, in other words, the target of receiving VAT can be achieved if PKP has a high level of compliance and vice versa.

The technique for collecting VAT on the delivery of pharmaceutical preparations from PBF to IFRS follows a self-assessment system and withholding tax system. The submission of pharmaceutical preparations from PBF to private IFRS adopts a self-assessment system. PBF as a seller is subject to taxable sellers who are required to collect, deposit and report VAT from IFRS Private buyers. The target of receiving VAT can be achieved if PKP has a high level of compliance and vice versa.

In carrying out the VAT obligation, the time of payment of VAT is affected by the time the tax invoice is made [23]. PBF, as a taxable entrepreneur, is obliged to make a tax invoice when supplying pharmaceutical preparations to IFRS. When the receipt of payment occurs before the supply of a pharmaceutical preparation, then when making a tax invoice is the time of receipt of payment [24]. The tax invoice is proof of tax collection made by PBF.

In the self-assessment system mechanism, the PBF will collect VAT when supplying the VAT to the private IFRS. If the PBF makes a combined tax invoice that is the supply of the pharmaceutical preparation to the same IFRS for one calendar month, then the tax invoice must be made no later than the end of the month the submission of the pharmacy [23]. 
Through the tax credit mechanism, if the tax collected by PBF is higher than the input tax, then the underpayment of VAT must be paid no later than the end of the following month. There is terms of payment applied from privat IFRS to PBF for 40 to 45 days [25]. If the PBF supply the pharmaceutical preparation to the Government IRFS, the government treasurer is determined to collect VAT. In the mechanism with the tax method, this system when depositing VAT will shift. For treasurers of IFRS, the collection of VAT is made at the time of payment by collecting directly from bills submitted by PBF. The terms of payment applied from government IFRS to PBF for 90 days [25].

Based on these term of payment provisions, means that with terms of payment from IFRS to PBF for 40 to 45 days, cash flow from PBF is not interrupted. Also, the government is guaranteed in receiving VAT paid by PBF under the normal VAT mechanism. In the other side, the transfer of VAT receipts from government IFRS to the state takes longer than the deposits made by the PBF. Bearing in mind the term of payment that applies to government IFRS to PBF is 90 (ninety) days after the goods are sent, and VAT is deposited to the country no later than seven days after the end of the payment month. As an illustration, it can be illustrated below that there are differences in the time for depositing VAT or the loss or delay of receiving VAT for 52 days. The Illustration of the differences in the deadline of payment can be seen in Table 1. below.

Table 1. Illustration of the differences in the deadline of payment

\begin{tabular}{|l|l|l|l|l|l|l|}
\hline $\begin{array}{l}\text { Supply from } \\
\text { PBS to IFRS }\end{array}$ & $\begin{array}{l}\text { Time of } \\
\text { Supply }\end{array}$ & $\begin{array}{l}\text { Time of Tax } \\
\text { Invoice } \\
\text { (between) }\end{array}$ & $\begin{array}{l}\text { Term of } \\
\text { comercial } \\
\text { Payment }\end{array}$ & VAT Due & $\begin{array}{l}\text { Cash } \\
\text { flow }\end{array}$ & $\begin{array}{l}\text { Potensial } \\
\text { loss of } \\
\text { Govnt Rev }\end{array}$ \\
\hline $\begin{array}{l}\text { Self- } \\
\text { assessment } \\
\text { system }\end{array}$ & 1 July & 1 to 31 July & $\begin{array}{l}40 \text { to } 45 \\
\text { days (10 to } \\
15 \text { Aug) }\end{array}$ & 15 Augt & 0 day & 0 day \\
\hline $\begin{array}{l}\text { Withholding } \\
\text { tax system }\end{array}$ & 1 July & 1 to 31 July & $\begin{array}{l}90 \text { days (30 } \\
\text { Sep) }\end{array}$ & 7 Oct & 52 days & 52 days \\
\hline
\end{tabular}

Source: processed directly by authors, 2019

\section{Discussion}

The VAT Collection Policy by the Government IFRS Treasurer is one of the peculiarities found in the collection system in Indonesia. Although this is a form of deviation from the normal mechanism, it is necessary to collect VAT through the Government Treasurer, given the low level of PKP compliance [26].

The VAT collection policy should meet the principle of neutrality, meaning that it does not distort PBF business activities in the supply of pharmaceutical preparations. The application of the self-assessment system to the supply of pharmaceutical preparations from PBF to private IFRS buyers allows PBF as a taxable entrepreneur who collects VAT to be able to credit the input tax to its output tax normally. VAT collection shifted from PBF to government IFRS buyers is a collection mechanism outside the general collection system. Administratively it will lead to inefficiencies in the PBF business.

Two conditions form the basis of these assumptions. First is the additional costs required by PBF in the context of carrying out refunds for overpaid VAT. Second is the amount of 
overpaid VAT, which is a cash flow burden considering the VAT restitution process, which takes longer than if PBF can credit input tax at each tax period. This is even more complicated when payment of bills from the Government IFRS to PBF often experiences delays. The dependence of the government's IFRS on the assistance of the Employment Social Security Administration Agency (BPJS) at the expense of BPJS patients, resulting in bills on the payment of pharmaceutical preparations being delayed.

Inefficiencies can also be analyzed from the provisions regarding when payment VAT is due. As has been illustrated previously in Table 1 Illustration of the differences in the deadline of payment, it means that, in addition to causing business distortion, the withholding tax system in the delivery of pharmaceutical preparations also effects in the interests of the government in obtaining revenue.

\section{Conclusion}

The technique for collecting VAT on the supply of pharmaceutical preparations from PBF to IFRS follows a self-assessment system and withholding tax system. The submission of pharmaceutical preparations from PBF to private IFRS adopts a self-assessment system. PBF as a seller is subject to the taxable entrepreneur are required to collect, pay and report VAT from IFRS Private buyers. The target of receiving VAT can be achieved if PKP has a high level of compliance and vice versa. The implementation of the withholding tax system is implemented when there is a supply of pharmaceutical preparations from PBF to the government IFRS. The provision of VAT collection that shifts to IFRS is a form of deviation from the normal mechanism, but the collection of VAT through the Government Treasurer needs to be done given the level of PKP compliance is still low.

The VAT collection policy should meet the principle of neutrality, meaning that it does not distort PBF business activities in the supply of pharmaceutical preparations. VAT collection shifted from PBF to government IFRS buyers is a collection mechanism outside the general collection system. In practice, it can influence PBF to submit pharmaceutical preparations. Administratively it will lead to inefficiencies in the PBF business. In addition, the transfer of VAT receipts to the state takes longer than the deposits made by the PBF caused by the difference of deadline for payment of billing terms and payment of VAT payable. 


\section{References}

[1] United Nations, „United Nations Development Programme,“ United Nations, New York, 2015.

[2] Republic of Indonesia, Law Number 36 Year 2009 about Heatlh, Indonesia, 2009.

[3] Ministry of Health Indonesia, „Strategic Plan of the Ministry of Health Year 2015-2019,“ 13 January 2015. [Online]. Available: http://farmalkes.kemkes.go.id/en/2015/01/rencanastrategis-kementerian-kesehatan-tahun-2015-2019/. [Cit. 2019 May 18].

[4] Republic of Indonesia, Decree of the Minister of Health of the Republic of Indonesia Number HK.02.02/MENKES/52/2015, Indonesia, 2015.

[5] Republic of Indonesia, Minister of Health Regulations Number 51 Year 2009 about Pharmaceutical Work, Indonesia, 2009.

[6] Republic of Indonesia , Law Number 44 Year 2009 About Hospital, Indonesia, 2009.

[7] Republic of Indonesia, Minister of Health Regulations Number 72 Year 2016 about Standards of Pharmaceutical Services in Hospitals, Indonesia, 2016.

[8] M. o. Health, „Hospital Recapitulation,“ RS Online, 2017. [Online]. Available: http://sirs.yankes.kemkes.go.id/rsonline/report/. [Cit. 19 January 2019].

[9] Republic of Indonesia, Minister of Health Regulations Number 1148/MENKES/PER/VI/2011 About Pharmaceutical Wholesaler, Indonesia, 2011.

[10] Republic of Indonesia, Law Number 42 Year 2009 on The Third Amandment of Law Number 8 Year 1983 on Value Added Tax of Goods and Services and Tax of Luxury Goods Sale, Indonesia: Indonesia, 2009.

[11] H. P. M. T. \&. I. S. E. Rosdiana, Teori Pajak Pertambahan Nilai: Kebijakan dan Implementasinya di Indonesia (Value Added Tax Theory: Policy and Implementation in Indonesia), Bogor: Ghalia Indonesia, 2011.

[12] Republic of Indonesia, Law Number 18 Year 2000 on The Second Amandment of Law Number 8 Year 1983 on Value Added Tax of Goods and Services and Tax of Luxury Goods Sale, Indonesia, 2000.

[13] T. Khausik, „What is Reverse Charge Mechanism under GST?,“ QuickBooks, [Online]. Available: https:/quickbooks.intuit.com/in/resources/gst-center/reverse-chargemechanism/. [Cit. 21 April 2019].

[14] A. a. O. O. Schenk, Value Added Tax A Comparative Approach, United Kingdom: Cambridge University Press, 2007.

[15] A. A. Tait, Value Added Tax- International Practice and Problems, Washington D.C: IMF, 1988.

[16] Republic of Indonesia, Regulation of The Minister of Finance of The Republic Indonesia Number 39/PMK.03/2018 on Procerdures for Preliminary Refund of Tax Overpayment, Indonesia: Indonesia, 2018.

[17] F. Baderi, „Utang BPJS Kesehatan (BPJS Health Debt),“ Neraca, 25 September 2018. [Online]. Available: http://www.neraca.co.id/article/106728/utang-bpjs-kesehatan. [Cit. 21 April 2019].

[18] L. Ebrill, The Modern VAT, Washington D.C: IMF, 2001. 
[19] B. Terra, Sales Taxation: The Case of Value Added Tax in the European Community, Deventer-Boston: Kluwer Law and Taxation Publisher, 1998.

[20] T. d. B. R.-R. Famulska, „Principle of VAT Neutrality and The Reverse Charge Mechanism,“ Journal of Financial Internet Quaterly, p. 4, 18 September 2018.

[21] J. W. Creswell, Research Design: Qualitative, Quantitatif, and Mix Methods Approaches 4th Edition, London: Sage Publication, Inc, 2014.

[22] T. M. Le, Value Added Taxation : Mechanism, Design, and Policy Issues, Paper on Practical Issues of Tax Policy in Developing Countries, Washington D.C: World Bank, 2003.

[23] Republic of Indonesia, Minister of Finance Regulation Number 151/PMK.03/2013 About Procedures for Making and Procedures for Correction or Reimbursement of Tax Invoice, Indonesia, 2013.

[24] Republic of Indonesia, Minister of Finance Regulation Number 242/PMK.03/2014 About the Procedures for Payment and Depositing Taxes, Indonesia, 2014.

[25] R. S. Siahaan, Interviewee, Interview. [Rozhovor]. 25 May 2019.

[26] Gunadi, Interviewee, Interview. [Rozhovor]. 28 May 2019. 